\title{
ПРІОРИТЕТИ ФІНАНСОВОГО КОНТРОЛІНГУ В УПРАВЛІННІ ВАРТІСТЮ ГОСПОДАРЮЮЧИХ СУБ'СКТІВ
}

\author{
DOI: 10.32620/cher.2018.4.06
}

\begin{abstract}
Постановка проблеми. В статті розкрито передумови, сутнісні характеристки та об'єкти фінансового контролінгу з позиції збереження та відтворення вартості господарюючих суб’єктів. Мета cmammi - розкриття концептуальних та організаційних засад фінансового контролінгу в контексті забезпечення ефективності управління вартістю господарюючих суб'єктів. Об'єкт дослідження - процес обрання пріоритетів фінансового контролінгу в управлінні вартістю господарюючих суб'єктів. Методи, використані в дослідженні: логічно-змістовний метод, системний підхід, методи наукового пізнання, метод індукції тощо. Гіпотеза дослідження. Наявність залежності розробки методичних засад щодо вдоскона-лення фінансового контролінгу в контексті забезпечення результативності управління вартістю від врахування ризику, формування та вимірювання системи драйверів вартості в межах контролінгу, нормалізація критеріїв результативності управління вартістю та оцінки стратегічної вартості підприємств. Виклад основного матеріалу. На основі системного підходу сформовано концептуальну модель фінансового контролінгу, яка інтегрує: мету, предметне поле, принципи, завдання, функції, інструменти. Оригінальність та практичне значення дослідження полягають в обгрунтуванні методичного інструментарію фінансового контролінгу, який об'єднує: методи фінансової діагностики, фінансового планування, аналізу, ризик-менеджменту, управлінського обліку, системи оцінки вартісних показників. Висновки дослідження. Поєднання інструментів менеджменту ЕВМ і фінансового контролінгу забезпечує інформаційну базу для прогнозування очікуваної ринкової та стратегічної вартості підприємств. Розкрито методичний підхід до стратегічної оцінки вартості компаній.
\end{abstract} Обгрунтовано організаційні засади фінансового контролінгу.

Ключові слова:

фінансовий контролінг, вартість підприємства, інструменти фінансового контролінгу, фінансова діагностика, менеджмент на основі очікувань (Expectation-Based Management-EBM).

\section{PRIORITIES OF FINANCIAL CONTROLLING IN VALUE MANAGEMENT OF THE ECONOMIC ENTITIES}

Formulation of the problem. The article describes the preconditions, the essential characteristics and objects of financial control from the point of view of preservation and reproduction of the value of economic entities. The aim of the research is the disclosure of the conceptual and organizational foundations of financial control in the context of ensuring the effective management of the value of economic entities. The object of the research is the process of selecting the priorities of financial control in the management of the value of economic entities. Methods used in the study: logical-content method, system approach, methods of scientific knowledge, method of induction. The hypothesis of research. The existence of a dependence of the development of guidelines for improving financial control in the context of ensuring the effectiveness of cost management from the risk taking, the formation and measurement of the value drivers system within the limits of control, the normalization of the criteria for the effectiveness of cost management and assessment of the strategic value of enterprises. The statement of basic materials. On the basis of the system approach, a conceptual model of financial controlling, which integrates: purpose, subject field, principles, tasks, functions, tools, is formed. The originality and practical significance of the research consist in substantiating the methodical tools of financial control, which

${ }^{1}$ Костирко Лідія Андріївна, д-р екон. наук, завідувач кафедри «Фінанси та банківська справа», Східноукраїнский національний університет імені Володимира Даля, м. Сєвєродонецьк, Україна.

Kostyrko Lydia, Professor, Ph.D. in Economics, Head of Finances and Banking Department Volodymyr Dahl East Ukrainian National University, Severodonetsk, Ukraine.

ORCID ID: 0000-0002-3447-2343

e-mail: lidiyakostyrko@gmail.com

${ }^{2}$ Свтушенко Марина Вікторівна, асистент кафедри «Корпоративні фінанси і контролінг», ДВНЗ «Київський національний економічний університеу імені Вадима Гетьмана», м. Київ, Україна.

Yevtushenko Maryna, assistant of Corporate Finance and Controlling Department, Kyiv National Economic University named after Vadym Hetman, Kiev, Ukraine.

ORCID ID: 0000-0002-0775-2737

e-mail: marinapanasyuk@ukr.net 
combines: methods of financial diagnostics, financial planning, analysis, risk management, management accounting, system of estimation of cost indicators. Conclusions of the research. The combination of EBM management tools and financial controlling provides an information base for forecasting the expected market and strategic value of enterprises. The methodical approach to the strategic assessment of the value of companies is outlined. The organizational principles of financial control are substantiated.

Key words:

financial controlling, cost of an enterprise, financial control instruments, financial diagnostics, expectsbased management (EBM).

\section{ПРИОРИТЕТЫ ФИНАНСОВОГО КОНТРОЛЛИНГА В УПРАВЛЕНИИ СТОИМОСТИ ХОЗЯЙСТВУЮЩЕГО СУБЪЕКТА}

Постановка проблемы. В статье раскрыто предпосылки, сущностные характеристки и объекты контроллинга с позиции сохранения и воспроизводства стоимости хозяйствующих субъектов. Цель статьи - раскрытие концептуальных и организационных основ финансового контроллинга в контексте обеспечения эффективности управления стоимостью хозяйствующих субъектов. Объект исследования - процесс избрания приоритетов финансового контроллинга в управлении стоимостью хозяйствующих субъектов. Meтодbl, использованнье в исследовании: логически-содержательный метод, системный подход, методы научного познания, метод индукции и тому подобное. Гипотеза исследования. Наличие зависимости разработки методических основ усовершенствования финансового контроллинга в контексте обеспечения результативности управления стоимостью от учета риска, формирования и измерения системы драйверов стоимости в пределах контроллинга, нормализация критериев результативности управления стоимостью и оценки стратегической стоимости предприятий. Изложение основного материала. На основе системного подхода сформирована концептуальная модель финансового контроллинга, которая интегрирует: цель, предметное поле, принципы, задачи, функции, инструменты. Оригинальность и практическое значение исследования заключаются в обосновании методического инструментария финансового контроллинга, который объединяет: методы финансовой диагностики, финансового планирования, анализа, риск-менеджмента, управленческого учета, системы оценки стоимостных показателей. Bblводы uccледования. Сочетание инструментов менеджмента ЭВМ и финансового контроллинга обеспечивает информационную базу для прогнозирования ожидаемой рыночной и стратегической стоимости предприятий. Раскрыто методический подход к стратегической оценки стоимости компаний. Обоснованно организационные основы контроллинга.

Ключевые слова:

финансовый контроллинг, стоимость предприятия, инструменты финансового контроллинга, финансовая диагностика, менеджмент на основе ожиданий (Expectation-Based Management).

Постановка проблеми. В умовах посилення глобалізації та динамічних змін ринкового середовища фінансовий контролінг є інструментом забезпечення сталого розвитку та конкурентоспроможності компаній. Створення дієвої системи фінансового контролінгу обумовлюється його можливістю своєчасно ідентифікувати внутрішні й зовнішні фактори впливу на вартість підприємств, аналізувати їх і розробляти заходи щодо адаптації суб’єктів господарювання до змін і попередження від можливих втрат, економічних вигід. Існує потреба в вимірюванні драйверів вартості підприємств, шляхом отримання якісної інформації для прийняття управлінських рішень. Проте система фінансового контролінгу в більшості вітчизняних компаніях не відповідає сучасним умовам ведення бізнесу: протиріччя між цілями управління і контролінгом, методики контролінгу не $є$ ризик-орієнтованими, про- цедури контролінгу обмежуються та орієнтуються на цілі поточного управління.

Аналіз останніх досліджень та публікацій. Дослідженню проблем становлення i розвитку контролінга присвячені наукові праці $[3,5,6,7,8,9]$ вітчизняних та зарубіжних вчених серед яких: Ю. Аніскін, I. О. Бланк, М. П. Бутко, Ю. Вебер, А. Дайлен, Н. Данілочкіна, С. В. Данилочкін, Р. С. Каплан, Х.-Ю. Кюппер, Е. Майер, Р. Манн, Л. Птащенко, Т. Райхман, В. Сержанов, О. О. Терещенко, С. Фалько, Х.-Й. Фольмут, Д. Хан, Р. Хілтон, П. Хорват,Ч. Хорнгрен, Д. Шнайдер, Х. Штіглер, А. І. Шигаєв, К. Штайнле. Незважаючи на наявність великої кількості наукових розробок в цій сфері подальшого дослідження та вирішення потребують ряд питань: розробка методичних засад щодо вдосконалення фінансового контролінгу в контексті забезпечення результативності управління вартістю 3 врахуванням ризику, формування та 
вимірювання системи драйверів вартості в межах контролінгу, нормалізація критеріїв результативності управління вартістю та оцінки стратегічної вартості підприємств.

Мета статті. Розкриття концептуальних та організаційних засад фінансового контролінгу в контексті забезпечення ефективності управління вартістю господарюючих суб'єктів.

Виклад основного матеріалу дослідження. Фінансовий контролінг на підприємствах утілює стратегічні цілі у форму конкретних показників, надає можливість обгрунтування потреби в капіталі та служить інструментом для прийняття управлінських рішень та ризику втрат вартості компаній. Для стейкхолдерів важливо мати чітке уявлення щодо забезпечення приросту вартості суб'єктів гоподарювання, тому стає необхідним пошук нових та вдосконалення вже існуючих інструментів фінансового контролінгу. Його методологія, методика та організація змінювалась на різних етапах розвитку економічних відносин. 3 огляду на те, що оцінка вартості організацій є первинною і управління організаціями здійснюється 3 метою іiі збереження, фінансовий контролінг слід розглядати як інструмент прийняття управлінських рішень. У даному дослідженні фінансовий контролінг розглядається у триєдиному підсумку як:

-система, інформаційної підтримки управлінських рішень, що передбачає використання методів планування, фінансової діагностики, управлінського обліку, внутрішнього контролю та ризикменеджменту, які в сукупності забезпечують координацію окремих підсистем управління та зорієнтовані на збереження та відтворення вартості підприємств на довгострокову перспективу.

-система попередження, що надає можливість оцінити втрати вартості у розрізі: бізнес-одиниць, підрозділів та видів діяльності суб'єктів господарювання.

- сукупність даних контрольної, аналітичної, діагностичної, облікової, статистичної, інших видів та узагальнення i модифікацію інформації 3 метою надання необхідної інформації різним групам користувачів та прийняття довготермінових управлінських рішень.

Залежно від завдань управління фінансовий контролінг розмежовується на: оперативний та стратегічний. Оперативний контролінг спрямований на підтримку поточної діяльності підрозділів через фінансове планування та підвищення їх вкладу в створення вартості. Стратегічний контролінг - фокусується на підтримці конкурентоспроможності, реалізації фінансової стратегії та ідентифікації майбутніх економічних вигід, загроз втрат і потреб в капіталі. Взаємозв'язок стратегічного i оперативного фінансового контролінгу досягається шляхом використання показників доданої вартості, операційного прибутку, рентабельності чистих активів і грошових потоків. В якості об'єктів фінансового контролінгу визначено: фінансові ресурси, фінансово-економічні процеси і фінансові результати, вартість та ризики підприємств. Предметом контролінгу $\epsilon$ сукупність процедур 3 планування, виявлення, вимірювання, узагльнення, модифікації й передачі інформації про процеси та результати господарської діяльності користувачам для прийняття управлінских рішень.

Виходячи 3 поставленої мети у сферу завдань фінансового контролінгу входить: аналіз сильних і слабких сторін діяльності, визначення цільових та стратегічних орієнтирів, забезпечення потреб користувачів 3 метою скорочення інформаційної асиметрії, ідентифікація та оцінка факторів вартості, попередження та усунення ризиків, контролінг ефективності виконання планів і рішень, оцінка ризиків бізнесу, фінансовий контролінг господарських операцій (доходи, витрати, грошові надходження, грошові видатки), розробка та моніторинг фінансової стратегії. В основу концепції фінансового контролінгу покладено координація та інтеграція всіх функцій управління підприємством, за допомогою узгодження інструментів, а саме: фінансового планування управлінського обліку; фінансової діагностики; системи показників та індикаторів вартості підприємств. Методологію фінансового контролінгу складають: мета, базові концепції, принципи, завдання, об'єкти, методичний інструментарій. Концептуальна модель фінансового контролінгу наведена на рис. 1 .

Розвиток теоретичних засад фінансового контролінгу базується на концепціях: вартості, менеджменту, ризикменеджменту, управлінського обліку, збалан- 
сування інтересів зацікавлених осіб, координації, безперервності.

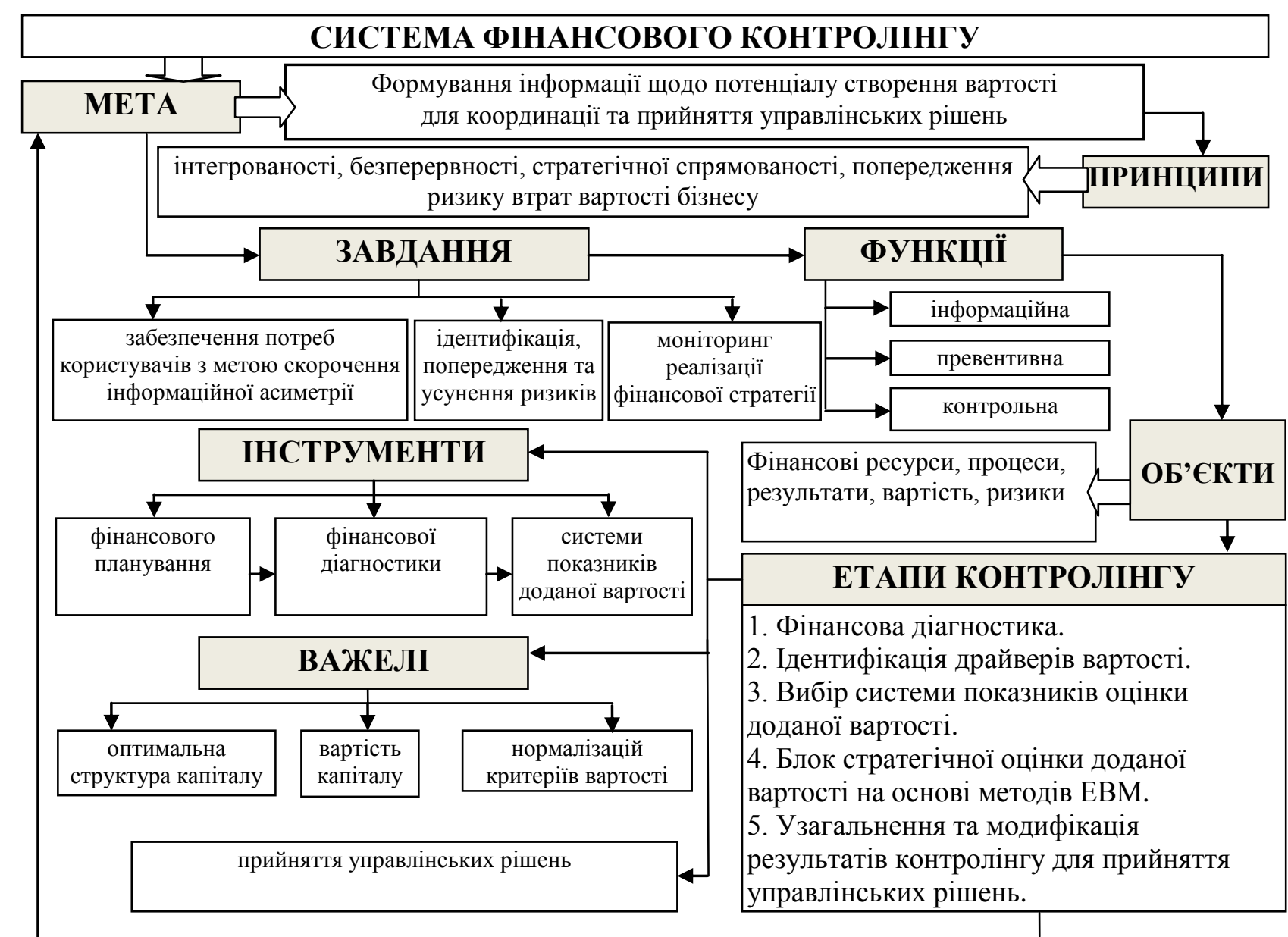

Рис. 1. Концептуальна модель фінансового контролінгу Джерело: розроблено авторами

Головна мета фінансового контролінгу: виявити і оцінити чинники, які впливають на підтримку й відтворення потенціалу збереження та відтворення вартості для прийняття управлінських рішень. Виходячи 3 цього основними завданнями фінансового контролінгу $\epsilon$ : формування релевантної інформації для потреб управління капіталом; фінансова діагностика впливу факторів вартості на ефективність прийняття управлінських рішень; інформаційне забезпечення фінансового планування; розробка заходів щодо попередження ризиків бізнесу.

Методологічним базисом фінансового контролінгу є принципи:

інтегрованості - проявляється в формуванні інформації для регулювання i координація управлінських рішень щодо збереження та відтворення вартості;

адаптивності - ідентифікація та модифікація інформації щодо змін ринкового середовища 3 метою попередження втрат економічних вигід від ризиків підприємницької діяльності;

безперервності - фінансовий контролінг орієнтується на непреривність контрольних процедур у відповідності з циклом управління капіталом для виявлення слабких сторін та резервів підвищення його ефективності;

стратегічної спрямованості

проявляється на етапі формування інформації та їі модифікації щодо створення вартості на майбутне для розробки $\mathrm{i}$ коригування стратегічних фінансових планів. У межах фінансового контролінгу оцінюються очікування менеджменту щодо майбутнього компанії, що дозволить користувачам спрогнозувати перспективи розвитку підприємства і можливі майбутні ризики;

зв'язності інформації фінансового контролінгу - означає, взаємозв'язок між показниками i прийняттям управлінських рішень ефективного використання капіталу 
та надання повного уявлення щодо динаміки створення вартості у часі;

цілеорієнтованості - передбачає формулювання та досягнення мети фінансового контролінгу. Виходячи 3 головної мети підприємств - забезпечення стабільного відтворення вартості, систему цілей необхідно розглядати за рівнями управління, видами діяльності та окремими факторами, що характеризують ефективність управління капіталом суб'єктів господарювання;

попередження загроз ризику втрат вартості бізнесу - означає контроль та оцінку фінансового стану об’єкта управління з метою ідентифікації та мінімізації впливу факторів на створення економічно доданої вартості. Критерієм прийнятяя управлінського рішення $€$ співвідношення між рентантабельністю інвестованого капіталу (ROI) та середньозваженої вартості капіталу (WACC).

Організація фінансового контролінгу орієнтована на створення та збереження вартості інтегрує наступні етапи.

Етап фінансової діагностики вирішує завдання щодо формування та модифікації інформації для оцінки майбутньої спроможності підприємств генерувати прибуток в створення доданої вартості та стратегічного позиціювання 3 метою прийняття управлінських рішень щодо вибору сценаріїв розвитку.

Етап драйверів вартості передбачає ідентифікацію та виявлення залежностей між доданою вартістю та потенціалом іiі створення. На цьому етапі формується інформація щодо ключових факторів доданої вартості, серед яких: обсяги продажів, собівартість, фінансові витрати, вартість власних джерел фінансування. Така інформація є підгрунтям для оцінювання необхідного обсягу власних i зовнішніх джерел фінансового потенціалу створення вартості 3 урахуванням можливості їх оптимізації.

Аналіз факторів створення (руйнування) бізнесом вартості здійснюється на основі таких показників, як: рентабельність власних джерел, рентабельність інвестованого капіталу, темп зростання власних джерел фінансування, WACC. Підприємства створюють вартість тоді, коли рентабельність власних джерел вища від їх вартості. Вона створює більше вартості, коли вона зростає. Однак, необхідно враховувати, що фінансові індикатори дозволяють оцінити лише резуль- тати діяльності суб'єктів господарювання, пов'язані з інвестиціями в матеріальні активи, поза увагою залишаються, наприклад, операції по довгостроковим контрактам 3 постачальниками і покупцями, порушення яких може призвести до втрат вартості компаній.

Етап вибору системи показників оцінки доданої вартості - припускає розрахунки фундаментальної та ринкової вартості. Показники, засновані на фундаментальній вартості оцінки бізнесу, відображають можливості отримання доходів підприємств в майбутньому, тобто, вони враховують період створення вартості. Для розрахунку фундаментальної вартості найбільш придатним є дохідний підхід.

Оцінка ринкової вартості підприємств передбачає використання порівняльного підходу та методів менеджменту ЕВM для оцінки економічно доданої i очікуваної вартості 3 метою зниження інформаційної асиметрії та задоволення інформаційних потреб стейкхолдерів.

Етап стратегічної оцінки потенціалу доданої вартості передбачає: визначення залежності між величинами доданої вартості і потенціалу створення вартості; вибір бази оцінки показників оцінки потенціалу доданої вартості; нормалізацію критеріїв результативності управління вартістю; виявлення чинників створення (руйнування) бізнесом вартості; ідентифікація та оцінка ризиків, що впливають на додану вартість; оцінка стратегічної вартості на основі оцінки потенціалу ефективності управління (ЕВМ) та ризику бізнесу.

Етап узагальнення та модифікації результатів контролінгу для прийняття управлінських рішень - забезпечує координацію, процес виконання управлінських рішень та створює зворотній зв'язок шляхом формування системи виявлення вартісних факторів та внутрішніх резервів генерування цінності у майбутньому Фінансовий контролінг у системі управління засновується на реалізації принципу контролю зміни ключових факторів вартості підприємств. Для прийняття управлінських рішень найбільш придатними $є$ поєднання інструментів стратегічного й оперативного контролінгу та використання їх різних комбінацій. Залежно від потреб користувачів показники деталізуються в розрізі кожного рівня управління. 
Оцінка вартості підприємств передбачає дослідження та виокремлення факторів, які впливають на генерування чи руйнування вартості. При цьому в процесі визначення факторів вартості важливо виокремити ключові 3 них і встановити залежність між ними та зміною вартості. Усі фактори, що впливають на вартість компаній можно поділити на три групи: мікро-, макрота глобальні. Глобальні та мікро- фактори слід відносити до зовнішнього середовища, а мікро - до внутрішнього. Правильний вибір генеруючих та руйнуючих факторів вартості, вплив яких носить комплексний характер, складають основу розвитку системи формування вартості підприємства.

Результати дослідження дозволяють стверджувати про наявність різних методів контролінгу, які достатньо повно висвітлені в літературі $[1$, 4, 5, 7]. Вибір методів здійснюється залежно від цілей і завдвнь менеджменту, які ставляться до контролінгу. Методичний інструментарій фінансового контролінгу, оріентованого на збереження та відтворення вартості, охоплює: фінансову діагностику, фінансове планування, SWOTаналіз, системи оцінки вартісних показників та індикатерів, ризик-менеджменту, управлінського обліку.

Системний підхід до організації фінансового контролінгу реалізується на основі комплексного поєднання інструментів фінансової діагностики, фінансового планування, аналізу ефективності управління капіталом 3 використання методів ЕВМ та ризику.

Центральним елементом фінансового контролінгу $€$ фінансова діагностика суб'єктів господарювання. Вибір методики та інструментарію фінансової діагностики є досить складним питанням. Існуючі вітчизняні методики передбачають наступні напрями аналізу: горизонтальний, вертикальний, трендовий, коефіцієнтний, факторний аналіз. $\mathrm{He}$ розкритими залишаються методичні підходи дофінансової діагностики підприємствзокрема: логічно-дедуктивні та евристичні [2], використання яких дозволяє надати цілісне уявлення, щодо стану діяльності компанії та спрогнозувати потенціал створення їх вартості. Для здійснення фінансової діагностики використовуються різні системи показників, що характеризують результати фінансовогостану за різними рівнями управління. Слід зазначи- ти, що результативність управлінських рішень відображається зміною показників. Тому вибір показників може змінюватися залежно від завдань діагностики i потреб користувачів в інформації. Інтегральну оцінку фінансового стану в основному здійснюють на основі використання коефіцієнтного аналізу за такими групами показників: ліквідності, платоспроможності, фінансової незалежності, рентабельності, ділової та ринкової активності, що детально розкриті в економічній літературі [1].

Основними недоліками фінансової діагностики підприємств на основі відносних показників є:обмеженість їх використання, в основному для здійснення ретроспективного аналізу;застосування єдиних нормативів,не враховують специфіку галузі підприємств; рентабельності власного капіталу розраховується на основі чистого прибутку на противагу світовій практиці - чистого грошового потоку; велика кількість аналітичних показників, що призводить до їх дублювання та тісної кореляції між собою, а також до неправильних висновків; результати фінансової діагностики не можуть бути використані для всебічного дослідження факторів, що впливають на ринкову вартість підприємств.

Для оцінки ринкової вартості підприємств на майбутнє найбільш придатними $€$ методи перспективної діагностики зокрема статистичні та евристичні методичні підходи. Використання змішаних методів на основі поєднання статистичних та евристичних методичних підходів надає можливість визначити причинно-наслідкові зв'язки, що розкривають закономірність змін фінансової стійкості підприємств та факторів, що впливають на прийняття управлінських рішень.

Вимірювання та нормалізація критеріїв результативності управління вартістю підприємств є важливим етапом фінансової діагностики. Оптимізація вартості суб'єкта господарювання, стає головною метою підприємця, a нормалізація критеріїв результативності управління вартістю пріоритетним завданням. Виходячи 3 цієї мети - фінансовими індикаторами для їі досягнення виступають: стратегічна ефективність (приріст вартості компанії); ефективність операційної діяльності; ефективність інвестиційної діяльності; ефективність фінансової діяльності. Основна ідея фінансового контролінгу ефективності 
діяльності підприємств полягає в ідентифікації та кількісному вимірі факторів генерації вартості. Система управління вартістю господарюючого суб'єкта тісно корелює 3 концептом забезпечення фінансової стійкості компанії, оскільки, майбутні вільні грошові потоки залежать від обраної бізнес-моделі.

Зарубіжний досвід використання систем управліннявартістю бізнесу свідчить, що найбільш універсальним для оцінки ефективності управління діяльністю підприємств і прийняття інвестиціних рішень є показник EVA (Economic Value Added економічна додана вартість) [7] та RCF (залишковий грошовий потік). EVA i RCF відображають внутрішню оцінку вартості підприємств одночасно в двох вимірах економічному і фінансовому. За умови, що операційний прибуток підприємства дорівнює грошовому потоку, то чисельно рівними будуть EVA i RCF. Співвідношення операційного грошового потоку та операційного прибутку $\epsilon$ показником, що характеризує фінансовий цикл компанії та ефективність управління взаєморозрахунками 3 контрагентами.

Показники EVA і RCF на відміну від інших можуть бути розраховані як для підприємств, так і для окремого їх підрозділу та слугувати індикаторами при прийняті стратегічних управлінських рішень. На підставі цільових стратегічних показників діяльності суб'єктів господарювання, можна визначити для кожного рівня управління, контрольні показники від оцінки ефективності роботи компанії в цілому до оцінки ефективністі роботи окремих іiі бізнесодинць та менеджерів, створюючи тим самим базу для системи мотивації персоналу. Напротивагу вище вказаному, ринкова додана вартость (MVA - Market Value Added) відображає суб'єктивну оцінку підприємства ринком.

Планування і аналіз діяльності результативністю управління вартістю підприємства здійснюються на основі вказаних вище показників, які закріплюються за конкретними бізнес одиницями (центрами відповідальності) у вигляді цільових орієнтирів. Набір показників визначається обраною моделлю вартісно-орієнтованого управління. Кожна модель може бути представлена відповідним набором ключових i похідних показників, що характеризують ефективність управління.

Вибір інструментів і методів фінансового контролінгу залежить від завдань та цілей управління. Для оцінки ефективності бізнес-одиниц, мотивації менеджерів та ринкової вартості найбільш придатними є використання інструментів менеджменту ЕВM [8]. Система управління вартістю, заснована на використанні інструментів менеджменту ЕВM, дозволяє оцінити як внутрішню так і ринкову вартість. При оцінці ефективності вартісноорієнтованого управління підприємством слід враховувати очікувані вільні грошові потоки, які компанії будуть генерувати. Згідно з цією концепцією ціна акцій за визначений період буде зростати, якщо створений за цей період економічний прибуток перевищує очікувану ринком прибутковість. ЕВМ дозволяе оцінити вартість на підставі стандартної методики дисконтування грошових потоків 3 урахуванням ризиків. Ідея полягає у наступному: очікувана величина прибутку за визначений період уже входить у вартість акцій на початок періоду. Показник ЕВМ визначається як різниця між фактичним i очікуваним економічним прибутком компанії i його підрозділів. Концепція ЕВМ передбачає використання порівняльного підходу до оцінки вартості підприємств. Інструментом формування системи очікувань виступають показники компаній-аналогів. Послідовність вибору показників по компаніям-аналогам передбачає: 1) визначення підприємств або бізнес-одиниць за аналогічними критеріями на ринку (темпи зростання продажу, ризик, рентабельність грошових потоків); 2) для кожної бізнесодиниці розраховується три очікуваних показника: рентабельність інвестованого капіталу, середньозважену вартість капіталу й інвестований капітал; 3) розрахунок спреду по компаніям-аналогам, як різниця між рентабельністю інвестованого капіталу й середньозваженою вартістю; 4) вибір показника спреду прибутковості для формування очікувань i розрахунку величини ЕВМ на основі спреду та прогнозованого рівня інвестованого капіталу бізнес-одиниці. При визначенні вартості, створеної з урахуванням очікувань (тобто, показника EBM) очікуваний економічний прибуток визначається як спред дохідності компаніїаналога помножений на інвестований капітал 
аналізованої бізнес-одиниці. Такий підхід дозволяє визначити вартість, створену аналогом за умови вкладень в нього очікуваного капіталу. Приріст вартості ЕВМ бізнесодиниць свідчить про зростання вартості акцій компаній за рахунок кращого функціонування ніж у ії̈ конкурентів.

Висновки та перспективи подальших досліджень. Системою здатною забезпечувати користувачів релевантною інформацією щодо потенціалу створення вартості підприємств та попередження ризиків втрат економічних вигід є фінансовий контролінг. Запропонований підхід до формування системи фінансового контролінгу орієнтований на вимірювання впливу вартісних факторів та нормалізацію критеріїв результативності управління підприємствами, що забезпечують його ефективність в системі прийняття управлінських рішень. Системне вимірювання драйверів вартості підприємств у межах реалізації превентивної функції фінансового контролінгу служить аналітичної базою для прийняття управлінських рішень i визначення параметрів вибору стратегії розвитку на довгострокову перспективу.

Використання методів менеджменту ЕВМ в системі фінансового контролінгу надає можливість здійснити перехід від оцінки ефективності діяльності підприємства в цілому до оцінки ефективності окремих його підрозділів на основі порівняння вартості зі значеннями очікуваної вартості для формування інформаційної бази з метою визначення сегментів, що не створюють додану вартість на майбутнє. Впровадження підходу до оцінки стратегічної доданої вартості з урахуванням ризику бізнесу сприятиме зниженню інформаційної асиметрії та прийняттю оптимальних управлінських рішень.

\section{Література}

1. Терещзенко O. O. Фінансовий контролінг: навчальний посібник / [О. О. Терещенко, Н. Д. Бабяк] . — К. : КНЕУ, 2013. 393 c.

2. Євтушенко М. В. Еволюція статистичних та евристичних методичних підходів фінансової діагностики підприємств у світі / Свтушенко М. В. // Часопис економічних реформ. - 2017.- № 2 (26). - С. 45-56.

3. Костирко Л. А. Пріоритети формування механізму вартісно-орієнтованого управління фінансами підприємств / Костирко Л. А.,
Кукса I. М. // Часопис економічних реформ. 2018.- № 2 (30). - С. 58-64.

4. Д. Хан ПиК: Планирование и контроль: концепция контроллинга / [Д. Хан] .М.: Финансы и статистика, 1997. - 765 с.

5. Контроллинг как инструмент управления предприятием / Е. А. Ананькина, С. В. Данилочкин, Н. Г. Данилочкина и др. ; под ред. Н. Г. Данилочкиной. - М. : ЮНИТИ, 2002. - 279 с.

6. Horvath $P$. Controlling / Peter Horvath. — [12 Auflage]. - Munchen, 2011. — 848 p. doi: 10.15358/9783800644551

7. Stewart B. The Quest for Value: a Guide for Senior Managers. New York: Harper Collins Publishers, 1991. 800 p.

8. Коупленд T. Expectations-Based Management. Как достичь превосходства в управлении стоимостью компании / Т. Коупленд, А. Долгофф; [пер. Э.В. Кондуковой]. - М. : Эксмо, 2009. - $384 \mathrm{c}$.

9. Kaplan R. Risk Management - The Revealing Hand / R. Kaplan, A. Mikes // Journal of Applied Corporate Finance. - 2016. - № 28(1). P. 8-18.

\section{References}

1. Tereshchenko, O. O. \& Babiak, N. D. (2013). Financial Controlling. Kyiv: KNEU, 393.

2. Yevtushenko, M. V. (2017). Evolution of statistical and heuristic methodological approaches to financial diagnostics of enterprises in the world. Time description of economic reforms, 2 (26), 4556.

3. Kostyrko, L. A. \& Kuksa, I. M. (2018). Priorities of the formation of the mechanism of value-oriented management of financial enterprises. Time description of economic reforms, 2(30), 5864.

4. D. Han PiK: (1997). Planning and control: the concept of controlling. Moscow: Finance and Statistics, 765.

5. Anankina, E. A. \& Danilochkin, S. V. \& Dalylochkina, N. G. (2002). Controlling as an enterprise management tool. Moscow: UNITI, 279.

6. Horvath, P. (2011). Controlling. 12 Auflage. Munchen, 848.

7. Stewart, B. (1991). The Quest for Value: a Guide for Senior Managers. New York: Harper Collins Publishers, 800.

8. Copeland, T. \& Dolgoff, A. (2009). Expectations-Based Management. How to achieve excellence in cost management company. Mocsow: Eksmo, 384.

9. Kaplan, R. \& Mikes, A. (2016). Risk Management - The Revealing Hand. Journal of Applied Corporate Finance, 28(1), 8-18. 